\title{
Conjuring Hands: The Art of Curious Women of Color - Corrigendum
}

gloria j. wilson, Joni Boyd Acuff and Vanessa López

DOI: https://doi.org/10.1017/hyp.2021.38; First published online by Cambridge University Press: 24 September 2021

In the initial publication of wilson et al. (2021), the names of authors gloria j. wilson and Vanessa López were printed incorrectly. The original publication has been updated to include the authors' correct names.

\section{Reference}

wilson, gloria j., Joni Boyd Acuff, and Vanessa López. "Conjuring Hands: The Art of Curious Women of Color.” Hypatia, first published online 24 September 2021. doi:10.1017/hyp.2021.38.

Cite this article: wilson gj, Acuff JB, López V (2021). Conjuring Hands: The Art of Curious Women of Color - Corrigendum. Hypatia 36, 581. https://doi.org/10.1017/hyp.2021.63

(C) The Author(s), 2021. Published by Cambridge University Press on behalf of Hypatia, a Nonprofit Corporation. This is an Open Access article, distributed under the terms of the Creative Commons Attribution licence (http://creativecommons.org/licenses/by/4.0/), which permits unrestricted re-use, distribution, and reproduction in any medium, provided the original work is properly cited. 